\title{
The effect of time and type of stress moderators on yield and yield components of cotton on conventional and double-cropping systems under saline conditions
}

\author{
BORZOUYI Zeinab, ARMIN Mohammad*i( and MARVI Hamid
}

\begin{abstract}
Background: Today, stress moderators are employed to mitigate crop loss due to the adverse effects of environmental stress. The current research aimed to investigate the impacts of time and stress moderator types on agro-physiological responses of cotton on conventional and double-cropping systems during 2017 and 2018 under saline conditions. A split-plot factorial experiment was carried out in a randomized complete block design with three replications. Cultivation system [conventional (recommended planting date) and double-cropping systems (sowing after harvest of wheat)] were considered as the main plots, and stress moderator type at four levels [water control, $2 \mathrm{mmol} \cdot \mathrm{L}^{-1}$ Salicylic acid (SA), $100 \mathrm{mmol} \cdot \mathrm{L}^{-1}$ Glycine betaine (GB), and $100 \mu \mathrm{mol} \cdot \mathrm{L}^{-1}$ sodium nitroprusside (SNP)] and application time (flowering and flowering + bolling stages) were regarded as subplots.

Results: Plant height, reproductive branch number, the number of bolls, 10-boll weight, 1 000-seed weight, biological yield, seed cotton yield, lint yield, chlorophyll a, chlorophyll b, carotenoids, total chlorophyll, sodium, potassium, and proline content were less in double-cropping system comparing with conventional system. Spraying with the stress moderators alleviated soil salinity effects on yield, yield components, and biochemical traits of cotton. SNP spraying led to maximum plant height, branch number, the number of bolls per plant, 10-boll weight and seed cotton yield. SA spraying yielded the highest 1000 -seed weight, biological yield, lint percentage and lint yield. The highest chlorophyll a, chlorophyll b, carotenoids, and total chlorophyll content resulted from SNP spraying. Yield, yield components, and biochemical traits did not respond to the stress moderator types in double-cropping system. However, the highest chlorophyll a, carotenoids, proline content, the number of bolls per plant, and seed cotton yield resulted from SNP spraying in conventional system. No statistically significant differences were observed between spraying with SNP and SA in most studied traits.
\end{abstract}

Conclusions: The results suggest that the optimum cotton planting time and SNP spraying could be recommended for producing the most suitable yield under saline conditions.

Highlights:

- External application of stress modulators increases salinity stress tolerance.

- Spraying with sodium nitroprusside has more moderating effect.

*Correspondence: Armin@iaus.ac.ir; moh_armin@yahoo.com Department of Agronomy and Plant Breeding, Sabzevar Branch, Islamic Azad University, Sabzevar, Iran original author(s) and the source, provide a link to the Creative Commons licence, and indicate if changes were made. The images or other third party material in this article are included in the article's Creative Commons licence, unless indicated otherwise in a credit line to the material. If material is not included in the article's Creative Commons licence and your intended use is not permitted by statutory regulation or exceeds the permitted use, you will need to obtain permission directly from the copyright holder. To view a copy of this licence, visit http://creativecommons.org/licenses/by/4.0/. 
- Agro-physiological response of cotton to moderators is stronger in early sowing.

- Maximum seed cotton yield was achieved at early sowing and spraying sodium nitroprusside.

- Delayed cultivation reduces cotton yield.

Keywords: Cotton, Glycine betaine, Salicylic acid, Salinity, Sodium nitroprusside, Sowing date

\section{Introduction}

Environmental stresses have always been considered as one of the causes of yield decline in crops. Among various environmental stresses types, salinity stress is the cause of more than a $50 \%$ reduction in crop yields (Liu et al. 2020). Although cotton was considered a semisalinity-resistant plant, salinity has adverse effects on its growth and development (Ahmed et al. 2020). Different strategies, such as managing the type of fertilizer, time of fertilizer application, planting pattern, use of resistant cultivars, and today's use of stress moderators, have been employed to alleviate the effects of salinity stress on crops. For example, improving effects of sodium nitroprusside ${ }^{1}$ (Rezapour et al. 2019), salicylic $\operatorname{acid}^{2}$ and putrescine (Bagheri and Mohammadalipour 2011; Yildirim et al. 2008), ascorbic acid, brassinosteroids, and melatonin tocopherols (Xiao et al. 2019) have been reported for the amelioration of tolerance to salinity stress in cotton. Glycine betaine ${ }^{3}$ spraying in cotton has been reported to augment lint yield, the number of bolls, the number of reproductive branches, and plant height but reduce boll shedding percentage, and promote early germination; however, it has no significant effects on boll weight (Ali et al. 2010). Besides GB, SA and SNP are also applied to alleviate salinity stress effects. Today, both of these substances are classified as plant hormones. In the case of external application of SNP in cotton, its foliar application of $0.05 \mathrm{~mol} \cdot \mathrm{L}^{-1}$ increases the yield and yield components, pigment contents, total soluble sugars, proline content, total free amino acids, phenolic content, soluble proteins, antioxidant, and antioxidant enzyme activities (Shallan et al. 2012). Noreen et al. (2012) also reported an increase in cotton growth and yield with SA consumption.

The cropping sequence affects the planting time by making land fallow. Harvesting of previous crop and cultivation of successive crop determines the planting time. Double-cropping cotton following wheat is essentially late-planted cotton. The cotton crops sown in wheat-cotton, sunflower- cotton, and maize-cotton sequence often

\footnotetext{
${ }^{1}$ Sodium nitroprusside (SNP).

2 Salicylic acid (SA).

${ }^{3}$ Glycine betaine (GB).
}

get late (Ahmed et al. 2020; Tariq et al. 2018). In many parts of Iran, cotton cultivation was delayed by about 1 month of the proper sowing date to harvest winter wheat and barley (Bagherabadi et al. 2019). Sedighi et al. (2012) reported that the delays in cotton planting after harvesting barley reduced the lint yield by more than $30 \%$ compared with its timely sowing. Low yields caused by late cotton cultivation compared with its planting at the optimal date have been attributed to its reduced reproductive period, heat stress due to increased temperature during early growth stages, shortened day length, and lower solar radiation than desired during the reproductive stages (Rahman et al. 2019).

Due to the relatively good tolerance of cotton to salinity stress, its cultivation in saline soils was considered by many farmers. Therefore, finding a simple solution for increasing its yield in saline conditions can lead to proper economic production. The use of stress moderators is a practical and low-cost method to alleviate environmental stresses effects on crops. However, little information exists about the effects of foliage time and moderator type on the cotton yield and the yield components. Hence, this research aimed to investigate the responses of cotton to the time and type of stress moderator in different planting dates under soil salinity conditions.

\section{Materials and methods}

This research was conducted on a private farm, located $10 \mathrm{~km}$ from Sabzevar at latitude $36^{\circ} 13^{\prime}-\mathrm{N}$, longitude $57^{\circ}$ $44^{\prime}$-E, and $990 \mathrm{~m}$ altitude above sea level during 2017 and 2018. According to the Köppen climate classification, the study area had a semi-arid climate with cold winters and hot summers and an average rainfall of $187.7 \mathrm{~mm}$. The maximum and minimum average temperatures are $37.7{ }^{\circ} \mathrm{C}$ and $-2{ }^{\circ} \mathrm{C}$ in July and January, respectively. The meteorological data (monthly weather data, maximum and minimum temperature, total rainfall, and sunshine hour) are given in Fig. 1. Climate data were obtained from Sabzevar Meteorological Station (Islamic Republic of Iran Meteorological Organization 2020).

A split-plot factorial experiment was carried out in a randomized complete block design with three replications. Cultivation system [conventional (recommended planting date) and double-cropping systems (sowing after harvest of wheat)] (Sedighi et al. 2012) 

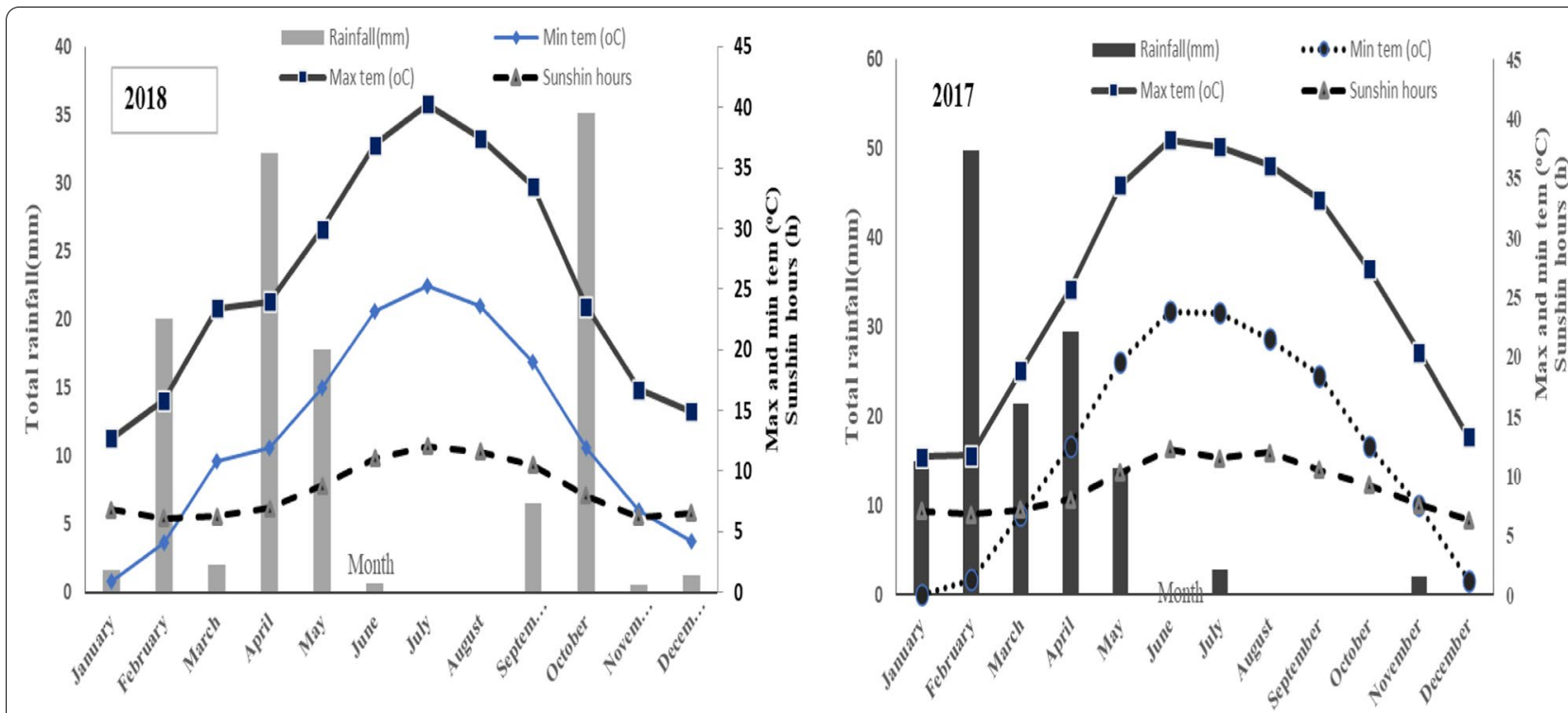

Fig. 1 Maximum and minimum temperatures, total rainfall and sunshine hours in the growing seasons during the 2 experimental years

Table 1 Physicochemical properties of the soil at the experimental site

\begin{tabular}{|c|c|c|c|c|c|c|c|c|c|c|c|c|}
\hline $\begin{array}{l}\text { Manganese } \\
/\left(\mathbf{m g} \cdot \mathbf{k g}^{-1}\right)\end{array}$ & Sodium & Zinc & Copper & Iron & $\begin{array}{l}\text { Phosphorus } \\
/\left(\mathrm{mg}^{\prime} \mathrm{kg}^{-1}\right)\end{array}$ & Potash & Nitrogen /\% & $\begin{array}{l}\text { Sand } \\
/ \%\end{array}$ & Clay & Silt & $\begin{array}{l}\mathrm{EC} \\
/\left(\mathrm{dS} \cdot \mathrm{m}^{-1}\right)\end{array}$ & $\mathrm{pH}_{(1: 5)}$ \\
\hline 7 & 40.5 & 0.55 & 0.46 & 2.42 & 4 & 110 & 0.02 & 63 & 13 & 24 & 10.5 & 7.2 \\
\hline
\end{tabular}

were considered as the main plots and stress moderator type at four levels [water control, $2 \mathrm{mmol} \cdot \mathrm{L}^{-1} \mathrm{SA}$, $100 \mathrm{mmol} \cdot \mathrm{L}^{-1} \mathrm{~GB}$, and $\left.100 \mu \mathrm{mol} \cdot \mathrm{L}^{-1} \mathrm{SNP}\right]$ and application time (flowering and flowering + bolling stages) as the subplots. In the flowering stage, foliar spraying was done approximately 40 45 days after emergence, and in bolling stages, foliar spraying was performed 60 65 days after emergence. Triton X100 was used as a surfactant at $1 \%$ concentration for better leaf area coverage during spraying. In the water control treatment, pure water spraying was performed. For spraying, a back sprayer with an 8002 nozzle at the pressure of $2 \mathrm{MPa}$ was utilized. The consumed water had a volume of $500 \mathrm{~L} \cdot \mathrm{ha}^{-1}$. Foliar spraying was performed in sunny weather with an average wind speed of $2 \mathrm{kmh}^{-1}$ in the afternoon during the two studied years. In the study area, the conventional and double-cropping systems are usually conducted from the 6th of May and June (after harvesting barley or wheat) onward, respectively. The experimental plots were laid fallow and allocated to wheat cultivation during the previous years of the 2017 and 2018 years on conventional and double-cropping systems. Land preparation was done with deep plowing in the fall of the previous year in 2017 and after wheat harvesting in 2018, and tillage operation included surface plowing, double-disc plowing, and complete leveling in May. Before planting, soil samples were taken at depths of $0-30 \mathrm{~cm}$, and physicochemical properties were determined (Table 1). According to the soil analysis results (Table 1), the studied soil was of a Sandy Loam type with a $\mathrm{pH}$ of $7.2, \mathrm{EC}$ of $10.5 \mathrm{dS} \cdot \mathrm{m}^{-1}$, and total $\mathrm{N}, \mathrm{P}$, and $\mathrm{K}$ contents of $0.02 \%, 110 \mathrm{mg} \cdot \mathrm{kg}^{-1}$ and $4 \mathrm{mg} \cdot \mathrm{kg}^{-1}$, respectively. A threshold salinity level, at which initial yield of cotton declines, is $7.7 \mathrm{dS} \cdot \mathrm{m}^{-1}$ with a $50 \%$ reduction in yield at $17.0 \mathrm{dS} \cdot \mathrm{m}^{-1}$ (Maas and Hoffman 1977).

According to the soil test, $160 \mathrm{~kg} \cdot \mathrm{ha}^{-1}$ of nitrogen from urea source was applied in the three stages: planting time $\left(45 \mathrm{~kg} \cdot \mathrm{ha}^{-1}\right)$, first weeding $\left(70 \mathrm{~kg} \cdot \mathrm{ha}^{-1}\right)$, and early flowering (45 kg.ha-1), along with $70 \mathrm{~kg} \cdot \mathrm{ha}^{-1}$ of $\mathrm{P}_{2} \mathrm{O}_{5}$ from triple superphosphate source before planting. Before sowing, the seeds were disinfected with Carboxin-Thiram (Vitavax) at a ratio of $2 \%$. To combat thrips pests, they were impregnated with Larvin (thiodicarb) at a ratio of $7 \%$. Each plot consisted of six rows with $5 \mathrm{~m}$ length, $50 \mathrm{~cm}$ between rows and a distance of $20 \mathrm{~cm}$ between plants in the rows. The main plot measured $15 \mathrm{~m}$ in 
length and $5 \mathrm{~m}$ in width and the size of each sub-plot was $3 \mathrm{~m}$ long and $5 \mathrm{~m}$ in width.

The sowing dates in conventional system occurred on May 4, 2017, and April 30, 2018, and the double-cropping system was on June 9, 2017, and June 7, 2018, respectively. In 2018, planting occurred after harvesting wheat with a combine harvester. The remaining straw and stubble were first collected with a blender, and other plant residues were mixed with soil using a rotating plow. Planting was done by using the delinted seeds of the Varamin cultivar and a pneumatic sowing machine. The 2 nd irrigation was performed 10 days later to prevent soil crusting and improve the germination condition of cotton seedlings. Irrigation was carried out according to the depletion of $40 \%$ of the total available water from the root zone during the whole experiment. Irrigation was applied equally to all treatments, according to the Agricultural and Natural Resources Research Center of Khorasan Province's recommendation (Sirjani et al. 2018). After complete establishment at 5-6-leaf-growing stage, the plants were thinned on rows at a distance of $20 \mathrm{~cm}$ from each other to achieve the desired density. Weeding operations were performed manually. Other required operations were carried out following local customs. The third terminally evolved leaves were selected in each of the two experimental years 2 weeks after applying the stress-moderating treatments to measure physiological traits based on their wet weights. The amounts of photosynthetic pigments (chlorophyll a, chlorophyll b, total chlorophyll, and carotenoids) were measured according to Arnon's (1967) method, and the concentrations of the pigments were calculated in milligrams per gram of fresh weight $\left(\mathrm{mg} \cdot \mathrm{g}^{-1} \mathrm{FW}\right)$. The method presented by Bates et al. (1973) was employed to measure the proline contents of the leaf tissues. The concentrations of sodium and potassium elements were measured with a JENWAY PFP7 flame photometer.

Harvesting operations were conducted at a single harvest time on November 10 and 25 in the first and second years, respectively. At the end of the growing season, ten plants per plot were randomly selected, and the plant height, the numbers of reproductive branches, the numbers of bolls per plant, and 10-boll weights were measured as the yield components. Seed cotton yield was measured after manually removing the marginal effects from $3 \mathrm{~m}^{2}$ of the middle rows of each plot. The lint percentage of the seed cotton was measured after separating the lint with laboratory saw ginning. Lint yield was calculated by multiplying the seed cotton yield by lint percentage, and seed yield was calculated by subtracting lint yield from seed cotton yield. One hundred cotton seeds were randomly separated and weighed using a digital scale with an accuracy of $0.01 \mathrm{~g}$ to determine the $1000-$ seed weight.
The analysis of variance (ANOVA) was done in SAS (Ver. 9.3) using PROC GLM. Sources of variation due to replication, year, sowing date, foliage time, modulator type, and the interaction of year, sowing date, foliage time, modulator type (all interaction) were used in the statistical model. Testing of homogeneity of the error mean squares from different locations or years are necessary for combined analysis. So, the test for homogeneity of error mean squares (variance) is necessary before taking up the combined analysis of variance. Bartlett's test or Hartley's test for homogeneity variance can be performed (Sahu 2016). The test of variance uniformity (Bartlett test) showed the uniformity of variance (Table 2); hence the data are presented as a combined year for all parameters. The least significant difference (LSD) test was utilized at a 5\% confidence level to compare the means, and Excel software was applied to draw the figures.

\section{Results}

\section{Yield and yield components}

Double-cropping system caused 36.2\%, 21.6\%, 49.3\%, $35.5 \%, 17.7 \%, 50.7 \%, 62.1 \%, 20.9 \%$, and $69.7 \%$ reductions in the final height, the number of reproductive branches, the number of bolls per plant, average weight of 10-bolls, 1000 -seed weight, biological yield, seed cotton yield, lint percentage, and lint yield, respectively (Table 3 ).

Foliar application at the flowering + bolling stages significantly increased plant height, the number of bolls, 10-boll weight, seed cotton yield, and lint yield by $8.8 \%$, $30.2 \%, 7.09 \%, 17.81 \%$, and $15.9 \%$, compared with the foliar application at the flowering stage, respectively. However, other studied traits did not display any statistical responses to the foliage time (Table 3).

Among the moderators, spraying with SNP led to the highest effects on increasing the height, branch number, boll number per plant, 10-boll weight, and seed cotton yield, while SA spraying produced the highest 1000 -seed weight, biological yield, lint percentage and lint yield (Table 3). Although GB enhanced 10-boll weight by $32.7 \%$ compared with the water control, the 10-boll weights were $4.92 \%$ and $9.05 \%$ lower than SA and SNP applications, respectively (Table 3). Additionally, no statistically significant difference was observed between foliar applications with SNP and SA for lint yield. Spraying with GB and SNP did not result in a statistically significant difference in 1000 -seed weight and biological yield. However, a statistically significant difference was found between SA and GB spraying in biological yield. Compared with the water control, foliar application with GB increased the number of reproductive branches; however, the highest number was obtained by foliar application with SNP, which did not have a statistically significant difference from that achieved by SA foliar application (Table 3). 


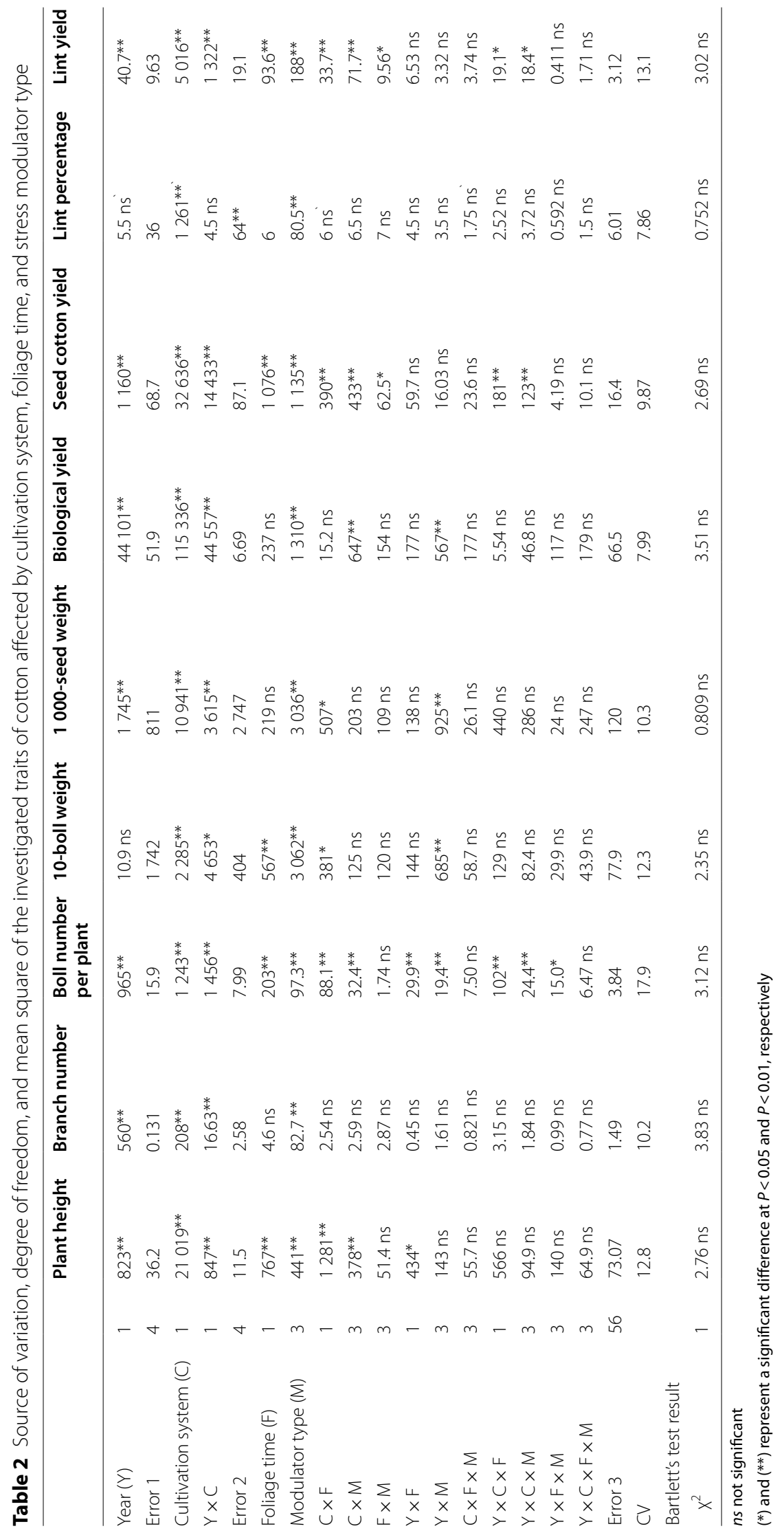


Table 3 The main effects of cultivation system, foliage time, and stress modulator type on the yield and yield components

\begin{tabular}{|c|c|c|c|c|c|c|c|c|c|}
\hline & $\begin{array}{l}\text { Plant height } \\
/ \mathrm{cm}\end{array}$ & $\begin{array}{l}\text { Branch } \\
\text { number }\end{array}$ & $\begin{array}{l}\text { Boll number } \\
\text { per plant }\end{array}$ & $\begin{array}{l}\text { 10-boll } \\
\text { weight /g }\end{array}$ & $\begin{array}{l}1000 \text {-seed } \\
\text { weight /g }\end{array}$ & $\begin{array}{l}\text { Biological } \\
\text { yield / } \\
\left(\mathbf{k g} \cdot \mathrm{ha}^{-1}\right)\end{array}$ & $\begin{array}{l}\text { Seed } \\
\text { cotton yield } \\
/\left(\mathrm{kg} \cdot \mathrm{ha}^{-1}\right)\end{array}$ & $\begin{array}{l}\text { Lint } \\
\text { percentage } \\
/ \%\end{array}$ & $\begin{array}{l}\text { Lint yield / } \\
\left(\mathbf{k g} \cdot \mathrm{ha}^{-1}\right)\end{array}$ \\
\hline \multicolumn{10}{|c|}{ Cultivation system } \\
\hline $\begin{array}{l}\text { Conven- } \\
\text { tional }\end{array}$ & $81.8 \pm 8.3^{a}$ & $13.4 \pm 3.6^{a}$ & $14.6 \pm 4.8^{\mathrm{a}}$ & $87.0 \pm 11.1^{\mathrm{a}}$ & $117 \pm 13.2^{\mathrm{a}}$ & $4323 \pm 35.2^{\mathrm{a}}$ & $1879 \pm 95.8^{a}$ & $34.8 \pm 2.4^{\mathrm{a}}$ & $655 \pm 84.9^{a}$ \\
\hline $\begin{array}{l}\text { Double- } \\
\text { cropping }\end{array}$ & $52.2 \pm 4.5^{b}$ & $10.5 \pm 3.1^{b}$ & $7.41 \pm 1.7^{\mathrm{b}}$ & $56.1 \pm 4.9^{b}$ & $96.2 \pm 26.9^{b}$ & $2131 \pm 141^{b}$ & $713 \pm 52.1^{b}$ & $27.5 \pm 4.1 b$ & $198 \pm 52.4^{b}$ \\
\hline \multicolumn{10}{|l|}{ Foliage time } \\
\hline Flowering & $64.2 \pm 6.3^{b}$ & $11.1 \pm 3.3^{\mathrm{a}}$ & $9.52 \pm 5.5^{b}$ & $69.1 \pm 11.7^{b}$ & $105 \pm 18.7^{\mathrm{a}}$ & $3277 \pm 51.5^{\mathrm{a}}$ & $1190 \pm 68.8^{b}$ & $31.4 \pm 4.8^{\mathrm{a}}$ & $395 \pm 25.7^{b}$ \\
\hline $\begin{array}{l}\text { Flower- } \\
\text { ing + bol- } \\
\text { ling }\end{array}$ & $69.9 \pm 11.1^{\mathrm{a}}$ & $12.7 \pm 3.7^{a}$ & $12.4 \pm 3.4^{\mathrm{a}}$ & $74.0 \pm 15.9^{a}$ & $108 \pm 27.8^{a}$ & $3177 \pm 52.9^{a}$ & $1402 \pm 84.6^{a}$ & $30.9 \pm 5.1^{a}$ & $458 \pm 30.1^{\mathrm{a}}$ \\
\hline \multicolumn{10}{|c|}{ Modulator type } \\
\hline $\begin{array}{l}\text { Water } \\
\text { control }\end{array}$ & $61.3 \pm 6.6^{b}$ & $9.52 \pm 2.9^{c}$ & $8.01 \pm 3.1^{b}$ & $55.2 \pm 7.1^{c}$ & $92.3 \pm 8.24^{c}$ & $2931 \pm 30.2^{c}$ & $1019 \pm 57.1^{c}$ & $28.8 \pm 4.8^{c}$ & $307 \pm 18.9^{c}$ \\
\hline GB & $66.4 \pm 6.1^{\mathrm{a}}$ & $11.6 \pm 3.5^{b}$ & $11.6 \pm 5.2^{a}$ & $73.3 \pm 13.7^{b}$ & $107 \pm 7.9^{b}$ & $3183 \pm 46.4^{b}$ & $1225 \pm 70.5^{b}$ & $32.0 \pm 3.8^{\mathrm{ab}}$ & $411 \pm 26.2^{b}$ \\
\hline SA & $69.5 \pm 11.9^{\mathrm{a}}$ & $13.0 \pm 3.2^{\mathrm{a}}$ & $11.9 \pm 3.6^{\mathrm{a}}$ & $77.1 \pm 11.7^{\mathrm{ab}}$ & $120 \pm 14.4^{\mathrm{a}}$ & $3487 \pm 96.2^{a}$ & $1467 \pm 84.8^{\mathrm{a}}$ & $33.0 \pm 4.8^{\mathrm{a}}$ & $504 \pm 31.7^{\mathrm{a}}$ \\
\hline SNP & $70.9 \pm 10.2^{\mathrm{a}}$ & $13.6 \pm 3.5^{\mathrm{a}}$ & $12.3 \pm 5.3^{\mathrm{a}}$ & $80.1 \pm 15.3^{\mathrm{a}}$ & $106 \pm 7.9^{b}$ & $3308 \pm 60.4^{b}$ & $1473 \pm 88.4^{\mathrm{a}}$ & $30.8 \pm 5.2^{b}$ & $483 \pm 32.4^{a}$ \\
\hline
\end{tabular}

Similar letters within the same column denote insignificant differences based on FLSD level of $5 \%$ (Mean \pm SD)

Plant height did not respond to foliage time in the double-cropping system; however, foliar application at the flowering + bolling stages led to a higher plant height than the foliar application at the flowering stage in the conventional system (Table 4). Both in the conventional and double-cropping systems, foliar application at the flowering + bolling stages produced more bolls per plant than the foliar application at the flowering stage. The highest (16.7) and lowest (6.86) numbers of bolls per plant were observed with foliar applications at the flowering + bolling and flowering stages in the conventional and double-cropping systems, respectively (Table 4). In the double-cropping system, 10-boll weight did not respond to the application time of the stress moderators; however, foliar application at the flowering + bolling stages led to $10.6 \%$ more 10 -boll weight than the foliar application at the flowering stage in the conventional system (Table 4). Seed cotton yield revealed the highest response to the consumption times of the moderators in both the conventional and double-cropping systems. In both cultivation systems, foliar applications at the flowering + bolling stages led to higher seed cotton yield compared with foliar applications in the flowering stage (19.89\% higher seed cotton yield in the conventional system, and $12.5 \%$ higher in the double-cropping system). The 1000 -seed weight responses to the foliage time and cultivation systems were similar to 10-boll weight (Table 4).

As with the foliage time, the type of moderator used affected the final height of cotton only in the conventional system, but the height did not indicate a statistically significant response to the use of moderators in the double-cropping system although the use of moderators elevated the height compared with the water control. In the conventional system, foliar application with GB had no significant effect on the height compared with the water control treatment; however, foliar application with SNP and SA enhanced the height by $22.15 \%$ and $21.32 \%$ compared with the water control, respectively (Table 5). Compared with the water control, foliar spraying with the moderators increased the numbers of bolls per plant up to $70.2 \%$ and $48.3 \%$ in the conventional and doublecropping system, respectively. SNP and SA spraying produced the highest boll number per plant, respectively, in the conventional and double-cropping systems (Table 5). In both conventional and double-cropping systems, foliar application with SA caused higher biological yield compared with other stress moderators. In the doublecropping system, the use of SNP reduced biological yield compared with GB, which was similar to that of the water control. Foliar application with SNP produced a biological yield identical to SA in the conventional system. The response of seed cotton yield to the type of moderator in the conventional system was higher. SNP, SA, and GB had statistically similar impacts on the seed cotton yield in the double-cropping system. However, foliar application with SNP produced higher seed cotton yield in the conventional system, which was not statistically significantly different from that induced by SA consumption (Table 5). In the double-cropping system, lint yield depicted less response to the type of consumed moderator, and all the moderators had a statistically similar effect on lint yield. Although GB spraying produced more lint yield than 


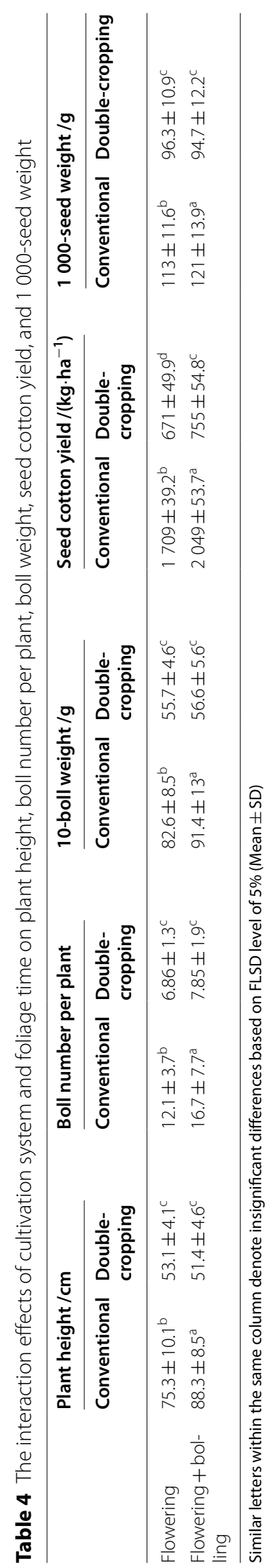




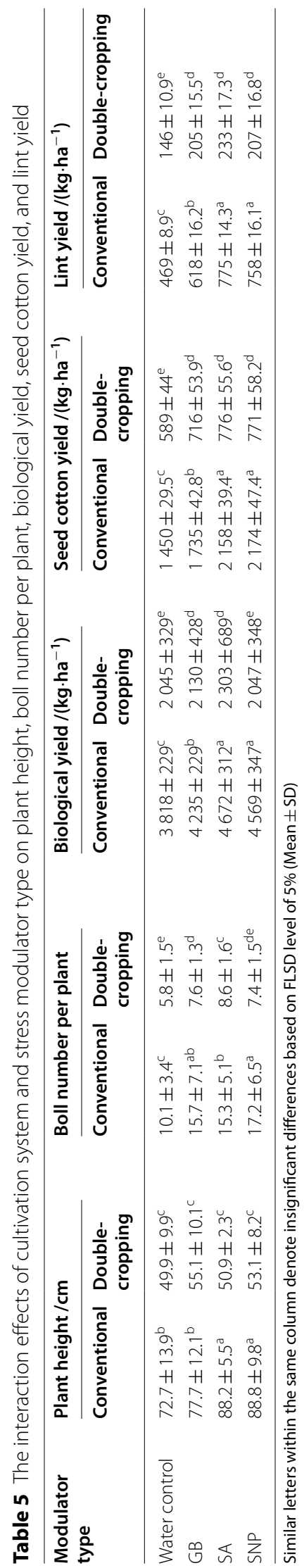


the water control treatment, the highest lint yield was observed with SA spraying in the conventional system (Table 5).

Foliar applications of all the stress moderators produced more seed cotton yield in the flowering + bolling compared with the flowering stage. The highest seed cotton yield was observed with SA foliar application in the flowering + bolling stages, which was not statistically significantly different from SNP application at this stage of the plant growth. Yet, a higher growth percentage of seed cotton yield (24.7\%) was seen with GB foliar application than other moderators in the flowering + bolling stages, while the enhancements were $22.2 \%$ and $15.9 \%$ for SA and SNP, respectively (Fig. 2).

Foliar spraying of all the moderators studied in this experiment yielded a higher lint yield in the flowering + bolling stages than foliar application in the flowering stage. SA foliar application in the flowering + bolling stages produced the highest lint yield, while its non-foliar application produced the lowest. There was no statistically significant difference between foliar applications with SA and SNP in the flowering + bolling stages (Fig. 3).

\section{Biochemical properties}

Double-cropping system lowered the contents of chlorophyll a, chlorophyll b, carotenoids, and total chlorophyll by $52.1 \%, 33.9 \%, 24.5 \%$, and $43.8 \%$, respectively (Table 6). Foliar application in the flowering + bolling stages increased chlorophyll a, chlorophyll b, and total chlorophyll contents compared with foliar application in the flowering stage. Among the consumed moderators, spraying with SNP had more beneficial effects on enhancing chlorophyll pigments than other stress moderators. Although GB spraying augmented the contents of chlorophyll pigments compared with the water control group, it had less elevating effects than other moderators. Compared with the water control, SNP spraying increased the contents of chlorophyll a, chlorophyll b, total chlorophyll, and carotenoids by 137\%, 160\%, 150\%, and $133 \%$, respectively (Table 6).

The proline content accumulated in the leaves in the conventional system was higher than that in the doublecropping system. Foliar spraying at the flowering + bolling stages also enhanced proline amount compared with the foliar application at the flowering stage. Comparison of the means of the treatments revealed that the highest proline content was obtained with SNP spraying, which did not have a statistically significant difference from that of SA. The lowest proline amount was observed in the non-spraying treatment. GB spraying also enhanced proline content compared with the water control (Table 6).
Both sodium and potassium contents were higher in the conventional system compared with the double-cropping system. Foliage time had only a significant effect on potassium content, and foliar application at the flowering + bolling stages displayed more impacts than that in the foliar application at the flowering stage. Under the conditions of this study, foliar application with SA played a higher role in reducing sodium content than other moderators; however, potassium content was not affected by the type of moderator used (Table 6).

At all levels of the consumed moderators, the content of chlorophyll a was lower in the double-cropping system compared with the conventional system (Table 7). Nonetheless, in both cultivations, spraying with SNP had more increasing effects on the chlorophyll a content compared with other moderators. In the conventional system, foliar application with SA had no statistically significant difference in chlorophyll a content from foliar application with SNP, and spraying with SA and GB were not statistically significantly different in the double-cropping system.

The highest carotenoid content was produced by spraying with SA and SNP in double-cropping and conventional system, respectively. The contents of carotenoids showed a higher response to foliar applications with the consumed moderators in the double-cropping system with the conventional system. Compared with the water control treatment, spraying with SNP resulted in 108\% and $168 \%$ enhancements of the contents of carotenoids in the conventional and double-cropping system, respectively (Table 7).

The proline content in the conventional system was higher compared with the double-cropping system although the difference was not statistically significant. However, spraying with SA produced the highest proline content in the double-cropping system, indicating a significant difference from SNP; however, it was not statistically significant with GB spraying (Table 7).

In both conventional and double-cropping systems, foliar application with SA significantly decreased sodium accumulation in the leaves. In the conventional system, no statistically significant difference was observed between the stress moderators in terms of the accumulation of sodium content, but spraying with GB compared with other studied moderators led to fewer reductive effects on sodium uptake in the double-cropping system, although it lowered sodium accumulation compared with the water control (Table 7).

In the conventional system, statistically significant differences were observed between all the consumed moderators for potassium uptake; however, no statistically significant difference was seen between spraying with SNP and GB. The highest rates of potassium uptake were 


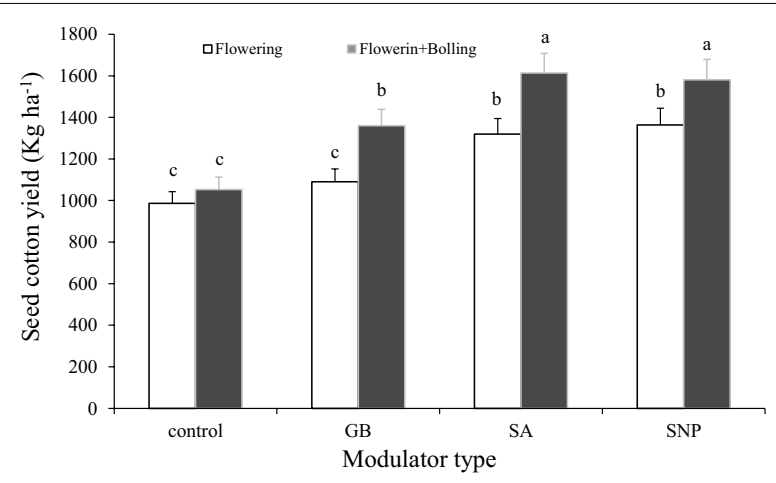

Fig. 2 The interaction effects of modulator type and foliage time on seed cotton yield

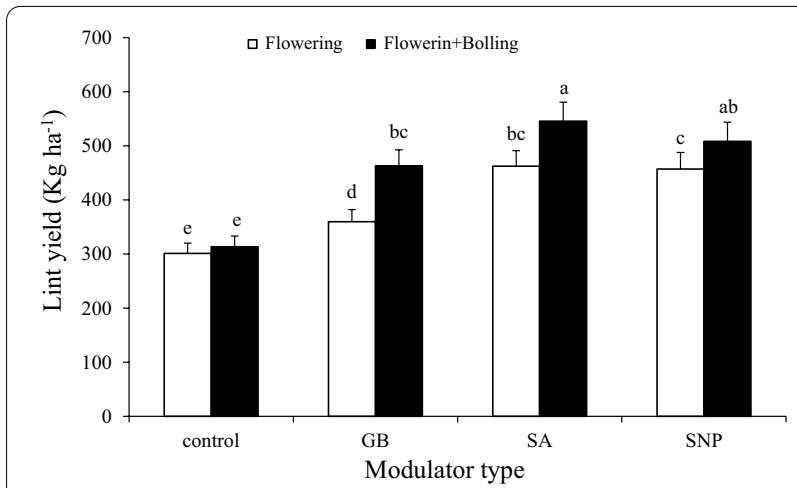

Fig. 3 The interaction effects of modulator type and foliage time on lint yield

documented with spraying with SNP and SA in the conventional and double-cropping systems, respectively (Table 7).

\section{Discussion}

Based on the results, cultivation system affected yield components, yield, and physiological traits. These findings are consistent with the previous reports on the effects of sowing dates on cotton. It was reported that the cotton cultivated on the 20th of August had a lower height compared with the plants cultivated on the 7th of July (Wrather et al. 2008). Similar to our results, a $25.84 \%$ decrease in the number of reproductive branches associated with delayed sowing was reported by Bagherabadi et al. (2019). The number of bolls per plant was also indicative of the negative response to delayed sowing with double-cropping. According to these results, Panjeh Koub et al. (2008) reported a $22 \%$ and $48 \%$ decrease in the number of bolls per unit area accompanied by the delays in the mid-time (June 10) and late (July 1) cotton cultivations compared with the usual sowing date (May 20). Pettigrew (2002) also reported that delays in cotton planting reduced the number of bolls per plant. Despite the higher number of bolls per plant, a decreased 10-boll weight was expected, but the increase in 10-boll weight in our conventional system might be since the boll growth time had been associated with suitable environmental conditions. In contrast, boll formation and development faced a high temperature and early autumn coldness in the delayed cultivation. As a result, the bolls had not grown and developed well. Similar to these results, Bagherabadi et al. (2019) reported that delays in cotton planting alleviated 10-boll weight by $34.02 \%$. Reduced food storage and reduced current photosynthesis are the reasons for lower 1000 -seed weight caused by delayed planting compared with the traditional sowing date (Bagheri and Mohammadalipour 2011). The highest and lowest 1000 -seed weights in cotton were reported in

Table 6 The main effects of cultivation system, foliage time, and stress modulator type on some biochemical properties

\begin{tabular}{|c|c|c|c|c|c|c|c|c|}
\hline & $\begin{array}{l}\text { Chlorophyll } a \\
/\left(\mathrm{mg}^{-1} \mathrm{FW}\right)\end{array}$ & Chlorophyll $b$ & Total chlorophyll & Carotenoid & $\begin{array}{l}\text { Proline } \\
/\left(\mu \mathrm{mol} . g^{-1}\right. \\
\text { FW })\end{array}$ & $\begin{array}{l}\mathrm{Na} \\
/\left(\mathrm{mg} \cdot \mathrm{g}^{-1} \mathrm{DW}\right.\end{array}$ & K & $\mathrm{Na} / \mathrm{k}$ \\
\hline \multicolumn{9}{|l|}{ Cultivation system } \\
\hline Conventional & $1.452 \pm 0.09^{\mathrm{a}}$ & $1.32 \pm 0.15^{\mathrm{a}}$ & $2.78 \pm 0.53^{\mathrm{a}}$ & $0.811 \pm 0.03^{\mathrm{a}}$ & $10.6 \pm 2.3^{\mathrm{a}}$ & $61.7 \pm 8.6^{\mathrm{a}}$ & $51.3 \pm 5.1^{\mathrm{a}}$ & $1.20 \pm 0.05^{\mathrm{a}}$ \\
\hline Double-cropping & $0.691 \pm 0.05^{b}$ & $0.872 \pm 0.07^{b}$ & $1.56 \pm 0.48^{b}$ & $0.612 \pm 0.02^{b}$ & $9.82 \pm 2.0^{b}$ & $52.1 \pm 4.7^{b}$ & $43.8 \pm 5.2 b$ & $1.18 \pm 0.04^{\mathrm{a}}$ \\
\hline \multicolumn{9}{|l|}{ Foliage time } \\
\hline Flowering & $0.982 \pm 0.67^{b}$ & $0.981 \pm 0.08^{b}$ & $1.96 \pm 0.27^{b}$ & $0.733 \pm 0.04^{\mathrm{a}}$ & $9.41 \pm 1.9^{b}$ & $56.2 \pm 5.4 a$ & $45.1 \pm 10.4^{b}$ & $1.28 \pm 0.04^{\mathrm{a}}$ \\
\hline $\begin{array}{l}\text { Flowering + bol- } \\
\text { ling }\end{array}$ & $1.02 \pm 0.08^{\mathrm{a}}$ & $1.22 \pm 0.11^{\mathrm{a}}$ & $2.39 \pm 0.34^{\mathrm{a}}$ & $0.682 \pm 0.03^{b}$ & $11.1 \pm 2.8^{\mathrm{a}}$ & $57.5 \pm 5.26^{\mathrm{a}}$ & $49.9 \pm 3.9^{\mathrm{a}}$ & $1.29 \pm 0.06^{\mathrm{a}}$ \\
\hline \multicolumn{9}{|l|}{ Modulator type } \\
\hline Water control & $0.581 \pm 0.02^{c}$ & $0.572 \pm 0.03^{c}$ & $1.15 \pm 0.06^{d}$ & $0.391 \pm 0.02^{d}$ & $7.45 \pm 0.81^{c}$ & $74.2 \pm 5.3^{\mathrm{a}}$ & $42.1 \pm 2.6^{b}$ & $1.71 \pm 0.03^{\mathrm{a}}$ \\
\hline $\mathrm{GB}$ & $1.15 \pm 0.07^{b}$ & $1.03 \pm 0.07^{b}$ & $2.18 \pm 0.08^{c}$ & $0.711 \pm 0.03^{c}$ & $10.8 \pm 1.19^{b}$ & $58.3 \pm 5.1^{b}$ & $48.9 \pm 5.5^{\mathrm{a}}$ & $1.31 \pm 0.05^{b}$ \\
\hline SA & $1.21 \pm 0.14^{b}$ & $1.31 \pm 0.12^{\mathrm{ab}}$ & $2.48 \pm 0.11^{b}$ & $0.822 \pm 0.02^{b}$ & $11.31 \pm 1.17^{\mathrm{a}}$ & $41.5 \pm 6.1^{d}$ & $50.2 \pm 5.8^{\mathrm{a}}$ & $0.861 \pm 0.03^{c}$ \\
\hline SNP & $1.38 \pm 0.18^{\mathrm{a}}$ & $1.49 \pm 0.09^{\mathrm{a}}$ & $2.87 \pm 0.09^{a}$ & $0.911 \pm 0.03^{\mathrm{a}}$ & $11.33 \pm 1.56^{\mathrm{a}}$ & $53.58 \pm 2.2^{c}$ & $48.8 \pm 7.2^{\mathrm{a}}$ & $1.18 \pm 0.04^{b}$ \\
\hline
\end{tabular}




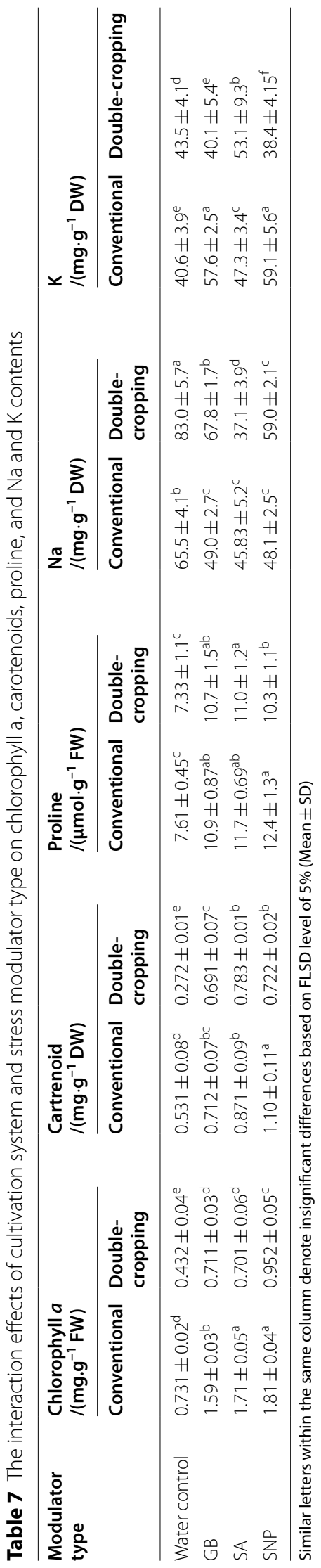


the conventional and double-cropping systems, respectively (Krzyzanowski and Delouche 2011). The delays in planting were associated with reduced biological yield. The decrease in biological yield was due to the reductions in plant height, the number of lateral branches, the number of bolls per plant, 10-boll weight, and lint weight per boll. Nemati (2000) reported that delays in the sowing date after the 13th of April would alleviate yields. In the same way as other traits, lint yield showed a similar response to planting delays in our study. Several results have been reported on the effects of sowing date on lint percentage. For example, Bednarz et al. (2005) believed that seed cotton growth and development would not fully occur in delayed sowing conditions, which could lower lint percentage.

Our studied traits indicated little response to the spray time. It seemed that the reason for non-responding to the foliage time in the double cropping cultivation was the short period between the two consumables. In this condition, cotton went through its vegetative stages earlier due to high temperatures, and thus the transition from the flowering to the bolling stage occurred rapidly. The use of moderators might have even hurt plant growth due to increasing doses, leading to a lack of response to foliage time. In dry stress conditions, spraying SA at a concentration of $100 \mathrm{mg} \cdot \mathrm{L}^{-1}$ in the flowering stage compared with foliar applications of GB and proline was reported to produce more beneficial effects in increasing yield and yield components in cotton. And the stress-moderating effects of GB were higher than those of proline (Noreen et al. 2012). Foliar spraying with GB during the flowering stage failed to produce a significantly higher yield compared with the water control treatment. Heitholt et al. (2001) linked cotton response to SA foliar application at different growth times to the increased resistance to diseases, insects, and microbes.

In our study, spraying with the stress moderators increased yield and yield components. It has been reported that SNP increases cotton plant growth and stem and root lengths in salinity stress. The enhanced plant growth is due to the augmented cell osmotic pressure, and improved cytoplasmic viscosity through high SNP concentrations would inhibit seedling growth (Dong et al. 2006). SA foliar application also increases indole acetic acid and cytokinin content in saline conditions and thus increases the height. Meek et al. (2003) reported that foliar application of GB led to a significant increase in the number of reproductive branches (having at least one boll per branch) compared with its non-consumption treatment. Similar to the above results, Zhang et al. (2011) reported that the numbers of reproductive branches and leaf areas in cultivars that can accumulate and synthesize GB and in transgenic lines capable of synthesizing it were statistically identical. Foliar application with SA enhances the number of bolls per plant by reducing transpiration rate, especially at high temperatures (Heitholt et al. 2001). As with other yield components, 1000 -seed weight was also elevated by spraying with the stress moderators. The use of stress modulators increases the period length and seed-filling rate, thus enhancing 1000 -seed weight (Bagheri and Mohammadalipour 2011) and preventing reductions of the number of seeds and their weights by augmenting their amounts of photosynthetic materials (Eraslan et al. 2007). With the use of stress moderators, lint yield, seed cotton yield, and seed yield increased. The role of SA in improving biochemical properties, such as contents of soluble and free proteins, photosynthetic pigments, and amounts of plant hormones, and enhancing lint yield under salinity stress conditions has been shown in many plants (Pakar et al. 2016). Wang et al. (2017) reported that SA caused maximum yield components by regulating plant growth processes, augmenting lint yield. In addition, the use of GB exogen resulted in $18 \%$ to $22 \%$ increases in cotton production (Naidu et al. 1998). In this study, the less response of cotton to the external use of GB appeared to be related to its ability to synthesize or accumulate GB by itself (Zhang et al. 2011). Given that lint percentage was not influenced by foliage time, the enhanced lint yield by foliar application in the flowering + bolling compared with the flowering stage was due to higher seed cotton yield in this treatment, as the lint yield was calculated by multiplying the seed cotton yield by lint percentage. Despite the high seed cotton yield in our SNP treatment, the reduced lint yield could be caused by the higher reduction of lint percentage compared with that triggered by SA foliar application.

Chlorophyll pigments responded to the cultivation system and moderator type as manifested by the amounts of chlorophyll pigments decreased in double-cropping system, whereas the use of moderators increased them in this study. Destructions of chloroplasts and photosynthetic structures, chlorophyll photooxidation, reaction with unique oxygen, destruction of chlorophyll synthesis precursors, inhibition of biosynthesis of new chlorophylls, activation of chlorophyll-degrading enzymes like chlorophyllase, and hormonal disorders are among the reasons for the decrease in chlorophyll levels under salinity stress conditions (Neocleous and Vasilakakis 2007). Ma et al. (2017) observed that salinity stress significantly reduced the contents of chlorophylls a and b, while treatment with SA reduced the reduction trends of their amounts. The increased role of SA in chlorophyll amounts was ascribed to the stimulation of enzymes associated with chlorophyll biosynthesis or inhibition of photosynthetic system disturbance, thereby alleviating 
chlorophyll degradation. Moreover, spraying with SA in saline conditions enhanced the contents of chlorophylls a and b, total chlorophyll, and carotenoids in cotton, which is in line with the results of this research. The reinforcing effects of SA on the photosynthetic capacity could be attributed to its stimulating effects on Rubisco's activity and pigment content (Tan et al. 2013). The improving effects of GB foliar application on increasing chlorophyll pigment content under salinity stress have been reported. In corn under salinity stress, the external GB application has had an increasing effect on chlorophyll pigments, which is one of the efficient factors in augmenting photosynthetic capacity in salinity conditions (Nawaz and Ashraf 2010).

Under salinity circumstances, proline accumulation takes place as a defense mechanism in plants. Proline is considered a non-toxic protective material to regulate osmosis in salinity and other environmental stresses (Mittler 2002). On the other hand, the accumulated proline in plants increases antioxidant capacity and neutralizes free hydroxyl radicals (Kasote et al. 2015). The external use of stress moderators enhanced proline content in cotton. According to the findings of this research, foliar application of SA in cotton under salinity conditions augmented proline amount, which enabled more resistance to stress via osmotic regulation. In addition, proline may act as an energy source that help improve the tolerance to salinity (El-Beltagi et al. 2017).

There is a difference in absorption between the two ions of sodium and potassium in saline conditions. The effects of various factors, such as salinity level or application of plant hormones, on changing the absorption amounts of sodium and potassium ions under salinity stress have been reported by various researchers (Babaei et al. 2021; Ghadakchiasl et al. 2017; Jayakannan et al. 2013; Mohsenzadeh and Zohrabi 2018; Sharif et al. 2019; Zheng et al. 2009). The modulating effects of hormones or semi-hormones in altering the uptakes of sodium and potassium ions are due to changes in plasma membrane permeability (Nadeem et al. 2016). Noreen et al. (2020) reported that stress modulators triggered more potassium uptake by changing plasma membrane penetrability. It has been reported that SA plays a higher role in reducing sodium accumulation in root and leaf tissues when salinity increases. Under the salinity level of $5 \mathrm{dS} \cdot \mathrm{m}^{-1}$, no statistically significant difference was observed between the use of gibberellin, cytokinin, and SA for lowering sodium accumulation. Spraying with gibberellin and cytokinin hormones failed to inhibit sodium accumulation after enhancing salinity to $15 \mathrm{dS} \cdot \mathrm{m}^{-1}$ either. Nevertheless, spraying with SA compared with the water control group reduced sodium absorption by $25 \%$. The lower response of sodium amount absorbed in the leaves to the foliar applications of the different consumed moderators seemed to be due to the salt concentration mechanism in crops. The absorbed salt frequently accumulates in the lower and older leaves of the plants in salinity conditions. Nazar et al. (2011) also reported that treatment with SA reduced the accumulation of sodium ions in the leaves and increased resistance to salinity. Similar to the above results, the decrease in sodium content and increase in potassium amount with the external use of SA in salinity stress conditions were reported by El-Tayeb (2005).

\section{Conclusion}

Overall, the results of this experiment demonstrated that the delay in cotton cultivation due to doublecropping reduced its yield components and ultimately economic performance by mitigating the amounts of chlorophyll pigments and thereby lowering the production of photosynthetic materials. Although in most of the studied traits, no statistically significant differences were observed between spraying during the flowering and flowering + bolling stages, foliar spraying at flowering + bolling stages was more suitable than flowering stage. Among the moderators applied in this experiment, the external use of SNP had more improvement effects on the studied traits; however, external use of SA was not statistically different from SNP in most traits. The external use of GB ameliorated the studied traits compared with the water control treatment, but the improvements were lower than those induced by SNP. Spraying with SNP increased the resistance of cotton to the experimental salinity conditions and thus enhanced yield by alleviating the sodium uptake and augmenting the amounts of chlorophyll pigments and proline and potassium contents. Finally, although the external applications of the stress moderators were not able to compensate for the adverse effects of delayed cultivation due to double-cropping, SNP consumption during the flowering + bolling stages could be recommended for conventional and double-cropping systems for proper yield achievement.

\section{Abbreviations \\ GB: Glycine betaine; SA: Salicylic acid; SNP: Sodium nitroprusside; LSD: Least significant difference.}

\section{Acknowledgements \\ The authors are grateful to the Sabzevar Natural Resources Research Center staff for their time and support in the experiment.}

\section{Authors' contributions}

Borzouyi Z carried out the study. Armin M designed the study, analyzed the $\mathrm{data}$, and wrote the main manuscript text, and Marvi $\mathrm{H}$ helped fulfill the experiment. All authors reviewed and approved the final manuscript. 


\section{Funding}

Not applicable.

\section{Availability of data and materials}

Not applicable.

\section{Declarations}

\section{Ethics approval and consent to participate}

Not applicable.

\section{Consent for publication}

Not applicable.

\section{Competing interests}

The authors declare that they have no competing interests.

Received: 15 April 2021 Accepted: 25 September 2021

Published online: 18 October 2021

\section{References}

Ahmed N, Chaudhry UK, Ali MA, et al. Salinity tolerance in cotton. In: Ahmad S, Hasanuzzaman M, editors. Cotton production and uses. Singapore: Springer; 2020. https://doi.org/10.1007/978-981-15-1472-2_19. Accessed 20 Mar 2021.

Ali S, Mohammad HF, Mohammad B. Evaluation of glycine betaine effects on some agronomic traits of cotton. J Agron Sci. 2010;1(1):67-76.

Arnon AN. Method of extraction of chlorophyll in the plants. Agronomy J. 1967;23:112-21.

Babaei S, Niknam V, Behmanesh M. Comparative effects of nitric oxide and salicylic acid on salinity tolerance in saffron (Crocus sativus). Plant Biosys Int J Dealing Aspects Plant Biol. 2021;155(1):73-82. https://doi.org/10. 1080/11263504.2020.1727975.

Bagherabadi $\mathrm{H}$, Armin M, Filekesh E. The effect of sowing date on yield and yield components of cotton planted in ultra narrow rows and conventional rows. Iran J Cotton Res. 2019;7(1):1-14. https://doi.org/10.22092/ ijcr.2019.108993.1073

Bagheri AR, Mohammadalipour Z. The effect of salicylic acid on growth, yield components in Glycin max L. under salinity stress. J Plant Ecophysiol. 2011:3(8):29-41.

Bates LS, Waldren RP, Teare I. Rapid determination of free proline for waterstress studies. Plant Soil. 1973;39(1):205-7.

Bednarz CW, Shurley WD, Anthony WS, et al. Yield, quality, and profitability of cotton produced at varying plant densities. Agron J. 2005:97(1):235-40.

Dong H, Li W, Tang W, et al. Yield, quality and leaf senescence of cotton grown at varying planting dates and plant densities in the Yellow River Valley of China. Field Crop Res. 2006;98(2):106-15. https://doi.org/10.1016/j.fcr. 2005.12.008.

El-Beltagi HS, Ahmed SH, Namich AAM, et al. Effect of salicylic acid and potassium citrate on cotton plant under salt stress. Fresenius Environ Bull. 2017:26(1a):1091-100.

El-Tayeb M. Response of barley grains to the interactive effect of salinity and salicylic acid. Plant Growth Regul. 2005;45(3):215-24. https://doi.org/10. 1007/s10725-005-4928-1.

Eraslan F, Inal A, Gunes A, et al. Impact of exogenous salicylic acid on the growth, antioxidant activity and physiology of carrot plants subjected to combined salinity and boron toxicity. Sci Hortic. 2007;113(2):120-8. https://doi.org/10.1016/j.scienta.2007.03.012.

Ghadakchiasl A, Mozafari A, Ghaderi N. Mitigation by sodium nitroprusside of the effects of salinity on the morpho-physiological and biochemical characteristics of Rubus idaeus under in vitro conditions. Physiol Mol Biol Plants. 2017:23(1):73-83. https://doi.org/10.1007/s12298-016-0396-5.

Heitholt J, Schmidt J, Mulrooney JE. Effect of foliar-applied salicylic acid on cotton flowering, boll retention, and yield. Mater Methods. 2001:46(2):105-9.

Islamic Republic of Iran Meteorological Organization. https://www.irimo.ir/ eng/wd/720-Products-Services.html. Accessed 20 Mar 2020.

Jayakannan M, Bose J, Babourina O, et al. Salicylic acid improves salinity tolerance in Arabidopsis by restoring membrane potential and preventing salt-induced K+ loss via a GORK channel. J Exp Bot. 2013;64(8):2255-68. https://doi.org/10.1093/jxb/ert085.

Kasote DM, Katyare SS, Hegde MV, et al. Significance of antioxidant potential of plants and its relevance to therapeutic applications. Int J Biol Sci. 2015;11(8):982-91. https://doi.org/10.7150/ijbs.12096.

Krzyzanowski FC, Delouche JC. Germination of cotton seed in relation to temperature. Revista Brasileira De Sementes. 2011;33(3):543-8. https:// doi.org/10.1590/s0101-31222011000300017

Liu M, Pan T, Allakhverdiev SI, et al. Crop halophytism: an environmentally sustainable solution for global food security. Trends Plant Sci. 2020; 25(7):630-4. https://doi.org/10.1016/j.tplants.2020.04.008.

Ma X, Zheng J, Zhang X, et al. Salicylic acid alleviates the adverse effects of salt stress on Dianthus superbus (Caryophyllaceae) by activating photosynthesis, protecting morphological structure, and enhancing the antioxidant system. Front Plant Sci. 2017:8:1-13. https://doi.org/10.3389/fpls.2017. 00600.

Maas EV, Hoffman GJ. Crop salt tolerance-current assessment. J Irrig Drain Div. 1977:103:115-34

Meek C, Oosterhuis D, Gorham J. Does foliar-applied glycine betaine affect endogenous betaine levels and yield in cotton? Crop Manag. 2003;2(1):110. https://doi.org/10.1094/cm-2003-0804-02-rs

Mittler R. Oxidative stress, antioxidants and stress tolerance. Trends Plant Sci. 2002;7(9):405-10. https://doi.org/10.1016/s1360-1385(02)02312-9.

Mohsenzadeh S, Zohrabi M. Auxin and sodium nitroprusside effects on wheat antioxidants in salinity. Russ J Plant Physiol. 2018;65(5):651-7. https://doi. org/10.1134/s1021443718050138.

Nadeem SM, Ahmad M, Zahir ZA, et al. Role of phytohormones in stress tolerance of plants. In: Hakeem KR, Akhtar MS, editors. Plant, soil and microbes. Springer, Cham. 2016. https://doi.org/10.1007/978-3-319-29573-2_17. Accessed 20 Jun 2021.

Naidu B, Cameron D, Konduri S. Improving drought tolerance of cotton by glycinebetaine application and selection. In: Proceedings of the 9th Australian agronomy conference, Wagga Wagga; 1998. http://www.regio nal.org.au/au/asa/1998/4/221 naidu.htm. Accessed 20 Jun 2021

Nawaz K, Ashraf M. Exogenous application of glycinebetaine modulates activities of antioxidants in maize plants subjected to salt stress. J Agron Crop Sci. 2010;196(1):28-37. https://doi.org/10.1111/j.1439-037x.2009.00385.x.

Nazar R, lqbal N, Syeed S, et al. Salicylic acid alleviates decreases in photosynthesis under salt stress by enhancing nitrogen and sulfur assimilation and antioxidant metabolism differentially in two mungbean cultivars. J Plant Physiol. 2011;168(8):807-15. https://doi.org/10.1016/j.jplph.2010.11.001.

Nemati N New topics in cotton farming Iran J Agric Sci. 2000:3(2):2-10.

Neocleous D, Vasilakakis $\mathrm{M}$. Effects of $\mathrm{NaCl}$ stress on red raspberry (Rubus idaeus L.'Autumn Bliss'). Sci Hortic. 2007;112(3):282-9. https://doi.org/10. 1016/j.scienta.2006.12.025.

Noreen S, Ashraf M, Akram NA. Does exogenous application of salicylic acid improve growth and some key physiological attributes in sunflower plants subjected to salt stress? J Appl Bot Food Qual. 2012;84(2):169-77.

Noreen S, Mahmood S, Faiz S, et al. Plant growth regulators for cotton production in changing environment. In: Ahmad S, Hasanuzzaman M, editors. Cotton production and uses. Singapore: Springer; 2020. https://doi.org/ 10.1007/978-981-15-1472-2_8. Accessed 20 Mar 2021.

Pakar N, Pirasteh-Anosheh H, Emam Y, et al. Barley growth, yield, antioxidant enzymes, and ion accumulation affected by PGRs under salinity stress conditions. J Plant Nutr. 2016;39(10):1372-9. https://doi.org/10.1080/ 01904167.2016.1143498.

Panjeh Koub A, Galeshi SA, Zeynali E, et al. Effect of planting date and plant density on morphological characteristics of cotton (Gossypium hirsutum cv. Siokra). J Agric Sci Nat Resour. 2008;14(5):25-38.

Pettigrew WT. Improved yield potential with an early planting cotton production system. Agron J. 2002;94(5):997-1003. https://doi.org/10.2134/agron j2002.0997.

Rahman MH, Ahmad A, Wajid A, et al. Application of CSM-CROPGRO-Cotton model for cultivars and optimum planting dates: evaluation in changing semi-arid climate. Field Crop Res. 2019;238:139-52. https://doi.org/10. 1016/j.fcr.2017.07.007

Rezapour R, Ganjali A, Abrishamchi P. Study of sodium nitroprusside (SNP) and salt stress interaction on some traits of canola plant (Brassica napus L. CV. Modena). J Plant Res. 2019;32(2):319-31.

Sahu PK. Applied statistics for agriculture, veterinary, fishery, dairy and allied fields. New Delhi: Springer; 2016 
Sedighi E, Sirousmehr A, Ramezani M, et al. Investigation the yield and qualitative traits of cotton under different planting dates in barley-cotton double cropping system. J Iran Plant Echophysiol Res. 2012;6(4):26-36.

Shallan MA, Hassan HM, Namich AA, et al. Effect of sodium niroprusside, putrescine and glycine betaine on alleviation of drought stress in cotton plant. Am Eurasian J Agric Environ Sci. 2012;12(9):1252-65.

Sharif I, Aleem S, Farooq J, et al. Salinity stress in cotton: effects, mechanism of tolerance and its management strategies. Physiol Mol Biol Plants. 2019:25:807-20. https://doi.org/10.1007/s12298-019-00676-2.

Sirjani M, Moghaddam MRR, Jamili O, et al. Technical instructions and extension recommendations to increase the yield of cotton in Khorasan Razavi. Mashhad, Iran: Khorasan Razavi Agricultural and Natural Resources Research and Education Mashhad Center; 2018. p. 19.

Tan BC, Chin CF, Alderson P. Effects of sodium nitroprusside on shoot multiplication and regeneration of Vanilla planifolia Andrews. In Vitro Cell Dev Biol-Plant. 2013;49(5):626-30. https://doi.org/10.1007/s11627-013-9526-8.

Tariq M, Afzal MN, Muhammad D, et al. Relationship of tissue potassium content with yield and fiber quality components of Bt cotton as influenced by potassium application methods. Field Crops Res. 2018; 229: 37-43. https://doi.org/10.1016/j.fcr.2018.09.012.

Wang N, Qi H, Qiao W, et al. Cotton (Gossypium hirsutum L.) genotypes with contrasting $\mathrm{K}^{+} / \mathrm{Na}^{+}$ion homeostasis: implications for salinity tolerance. Acta Physiol Plantarum. 2017;39(2):77. https://doi.org/10.1007/ s11738-017-2381-1.

Wrather J, Phipps B, Stevens W, et al. Cotton planting date and plant population effects on yield and fiber quality in the Mississippi Delta. J Cotton Sci. 2008;12(1):1-7.

Xiao S, Liu L, Wang H, et al. Exogenous melatonin accelerates seed germination in cotton (Gossypium hirsutum L.). PLoS ONE. 2019;14(6):e0216575. https://doi.org/10.1101/618959.

Yildirim E, Turan M, Guvenc I. Effect of foliar salicylic acid applications on growth, chlorophyll, and mineral content of cucumber grown under salt stress. J Plant Nutr. 2008;31(3):593-612. https://doi.org/10.1080/01904 160801895118

Zhang K, Guo N, Lian L, et al. Improved salt tolerance and seed cotton yield in cotton (Gossypium hirsutum L.) by transformation with betA gene for glycinebetaine synthesis. Euphytica. 2011;181(1):1-16. https://doi.org/10. 1007/s10681-011-0354-9.

Zheng C, Jiang D, Liu F, et al. Exogenous nitric oxide improves seed germination in wheat against mitochondrial oxidative damage induced by high salinity. Environ Exp Bot. 2009;67(1):222-7. https://doi.org/10.1016/j. envexpbot.2009.05.002
Ready to submit your research? Choose BMC and benefit from:

- fast, convenient online submission

- thorough peer review by experienced researchers in your field

- rapid publication on acceptance

- support for research data, including large and complex data types

- gold Open Access which fosters wider collaboration and increased citations

- maximum visibility for your research: over 100M website views per year

At BMC, research is always in progress.

Learn more biomedcentral.com/submissions 